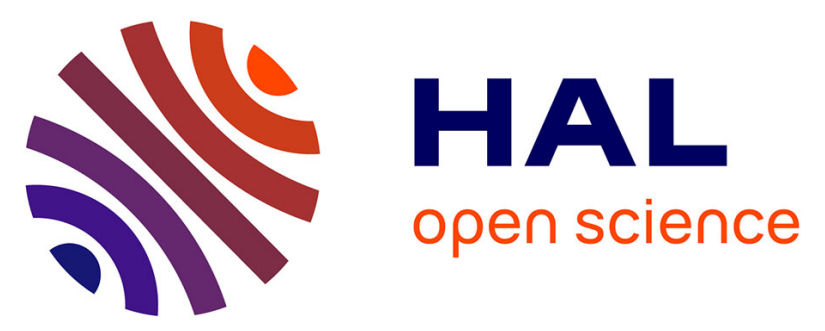

\title{
Mapping wildland-urban interfaces at large scales integrating housing density and vegetation aggregation for fire prevention in the South of France
}

C. Lampin-Maillet, M. Jappiot, M. Long, C. Bouillon, D. Morge, J.P. Ferrier

\section{- To cite this version:}

C. Lampin-Maillet, M. Jappiot, M. Long, C. Bouillon, D. Morge, et al.. Mapping wildland-urban interfaces at large scales integrating housing density and vegetation aggregation for fire prevention in the South of France. Journal of Environmental Management, 2009, 91, p. 732 - p. 741. 10.1016/j.jenvman.2009.10.001 . hal-00456152

\section{HAL Id: hal-00456152 \\ https://hal.science/hal-00456152}

Submitted on 12 Feb 2010

HAL is a multi-disciplinary open access archive for the deposit and dissemination of scientific research documents, whether they are published or not. The documents may come from teaching and research institutions in France or abroad, or from public or private research centers.
L'archive ouverte pluridisciplinaire HAL, est destinée au dépôt et à la diffusion de documents scientifiques de niveau recherche, publiés ou non, émanant des établissements d'enseignement et de recherche français ou étrangers, des laboratoires publics ou privés. 


\title{
Mapping wildland-urban interfaces at large scales integrating housing
}

\section{density and vegetation aggregation for fire prevention in the South of}

\section{France}

Corinne Lampin-Maillet ${ }^{\mathrm{A}, \mathrm{C}}$, Marielle Jappiot ${ }^{\mathrm{A}}$, Marlène Long ${ }^{\mathrm{A}}$, Christophe Bouillon $^{\mathrm{A}}$, Denis Morge ${ }^{\mathrm{A}}$ , Jean-Paul Ferrier ${ }^{\mathrm{B}}$

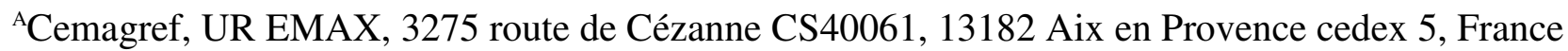

${ }^{\mathrm{B}}$ Aix-Marseille I University, Emeritus Professor, Aix-En-Provence, France

${ }^{\text {C } C o r r e s p o n d i n g ~ a u t h o r . ~ E m a i l: ~ c o r i n n e . l a m p i n @ ~ @ e m a g r e f . f r, ~ T e l: ~+33442669963 ~}$

\begin{abstract}
Every year, more than 50000 wildland fires affect about 500000 hectares of vegetation in southern European countries, particularly in wildland-urban interfaces (WUI). This paper presents a method to characterize and map WUIs at large scales and over large areas for wildland fire prevention in the South of France. Based on the combination of four types of building configuration and three classes of vegetation structure, twelve interface types were classified. Through spatial analysis, fire ignition density and burned area ratio were linked with the different types of WUI. Among WUI types, isolated WUIs with the lowest housing density represent the highest level of fire risk.
\end{abstract}

Keywords: Spatial analysis; GIS; Aggregation index; Wildland fire risk; Wildland-urban interface 


\section{INTRODUCTION}

Wildland fires affect large areas and cause great damage that has ecological, social and economic consequences. More than 50,000 wildland fires affect about 500,000 hectares of vegetation every year in southern European countries (JRC, 2006; Lampin-Maillet, 2008). Wildand-urban interfaces (WUIs) are directly concerned by wildland fire: $90 \%$ of wildland fires are caused by human activities in Mediterranean Europe (Eufirelab, 2004), and every year a number of people living in WUIs are killed by wildland fires. In the context of high urban pressure and the accumulation of wildland biomass, WUIs represent serious problems in terms of fire risk management (Davis, 1990; Velez, 1997; Cohen, 2000), particularly regarding two fire risk components: hazard, in terms of fire ignition caused by human activities, and vulnerability, in terms of burned areas threatening inhabited areas (Hardy, 2005; Jappiot et al, 2009).

According to Stewart et al. (2007), "the term wildland-urban interface is now used almost exclusively in the context of wildland fire"; but in fact there are different ways to define WUI. A wildland-urban interface is an area where houses meet or intermingle with undeveloped wildland vegetation. Specifically developed areas that abut wildland vegetation are characterized as WUI (Davis, 1990; USDA-USDI, 1991 in Nowicki, 2002; Radeloff et al., 2005a; Theobald \& Romme, 2007). WUIs are also areas where urban areas meet and interact with rural areas (Vince et al., 2005 in Avalapati et al., 2005), i.e. the zone where human development features intermingle with wildland vegetation (Collins, 2005).

In the present paper, we use the term WUI to refer to the conjunction of housing and vegetation characteristics (Stewart et al., 2007). Human presence is measured by the density of houses and other infrastructures (Lampin et al., 2006a, 2006b; Caballero, 2004; Camia et al., 2003) or by the density of the population (Kamp \& Sampson, 2002). In this paper, houses and buildings are dwellings. The configuration of houses was quantitatively defined and classified in four configuration types: isolated, scattered, dense or very dense (Lampin-Maillet et al., 2009). Vegetation is defined as wildland forests (coniferous, deciduous, and mixed forest), scrublands, transitional lands (mostly clear-cuts) (Stewart et al., 2003; Radeloff et al., 2005b; Lampin et al., 2006a). Fuel maps are essential for computing fire risk across a landscape by characterizing the horizontal and vertical structure of the vegetation. But making fuel maps is an extremely difficult and complex process (Keane et al., 2001). 
Firstly, data referring to the extent and location of WUIs are empirical and scarce, specifically for the purpose of land and fire management. Some methods developed at national or regional scales already allow the location and mapping of WUIs and provide tools for the elaboration of physical, emergency and self protection plans. However, according to Dumas et al. (2008) and Theobald \& Romme (2007), more detailed data are required for planning and management activities. Consequently an efficient method for mapping WUI is urgently needed for fire risk management.

Secondly, the question of how patterns of human settlement affect fire risk is of increasing importance for urban planning (Collinge, 1996; Alberti, 1999) in terms of fire prevention, i.e. the mitigation of fire ignition potential and the mitigation of burned areas in WUIs. According to a number of authors ( Syphard et al. 2007a; Cardille et al. 2001; Pew \& Larsen 2001, Haight et al. 2004; Badia-Perpinya \& Montserrat-Pallares, 2006), ignition sources are linked to the spatial arrangement of houses and continuous vegetation. Accurate knowledge of the relation between spatial organisation of WUI and wildfire risk is thus required.

\section{Objectives}

Our starting hypothesis was that wildfire risk is related to the spatial organisation of the territory with respect to the configuration of houses and the aggregation of the vegetation.

The objectives of our study were therefore to: (i) define and to map objective quantitative criteria to characterize vegetation structure and configuration of houses and (ii) determine whether WUI types are related to fire risk according to the density of fire ignition and the burnt area ratio.

This paper describes a reproducible method to characterise and map WUI at a large scale over a large area and to assess the links between WUI types and wildfire risk according to wildfire history.

\section{MATERIALS AND METHODS}

\section{Study area}

The study area (Fig.1) is located in south-eastern France in the Metropolitan area between Aix-enProvence and Marseille in Bouches-du-Rhône (43²3'57” N, 5²2’00” E). It covers around 167670 ha including 59 municipalities. Forestland (forests and scrubland) represents $60 \%$ of this area, urban areas represent $20 \%$ and agricultural land 20\%. The level of urbanization (420 inhabitants per $\mathrm{km}^{-2}$ ) and urban pressure are high. Urban sprawl and wildland are gradually replacing agricultural fallows hence increasing the extent of wildland-urban interfaces. Community leaders in the study 
area were concerned about the risk of wildland fire characterized by high fire ignition frequencies with around 165 fire ignitions and 200 ha burned per year over the last 10 years.

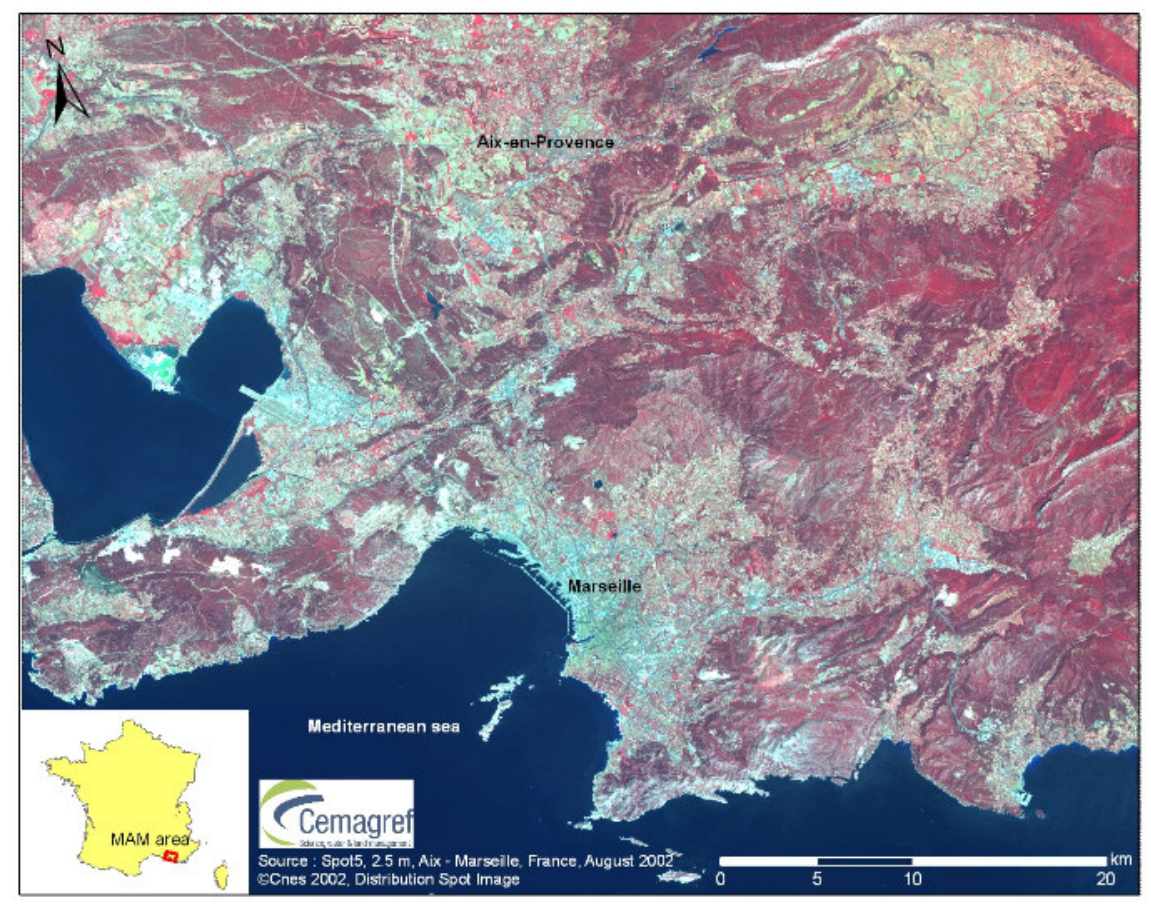

Figure 1: Study area in the South of France

\section{Data}

Characterisation and mapping of the WUI was based on land cover information extracted from remote sensing images and other sources: vegetation data came from a supervised classification of a Spot 5 multi-spectral 2.5-m pan-sharpened image captured in August 2002 and purchased in the framework of the ISIS program by CNES (National Centre of Spatial Studies). The resulting thematic raster layer divided the territory into two classes: a vegetation class and a non-vegetation class. Data on houses came from a vector layer made by the French National Geographical Institute (BD TOPO®) and updated using the previously mentioned Spot 5 image.

The relationship between WUIs and the spatial organisation of the land cover was derived from a thematic land cover map made in 2004 by the CNES. The most detailed level of this database describes the territory according to 57 classes.

The relationship between WUIs and fire risk was derived from two databases containing information on past fires: (1) a digitized database of fire ignition points (vector layer) created by the French National Forestry Institute. This database contains 565 fire ignition points corresponding to a fire covering than one hectare recorded between 1997 and 2007 with an accuracy of 10 meters and (2) a digitized database containing information on burned areas (vector layer) produced by the Agricul- 
. Lampin-Maillet C.,Jappiot M., Long M., Bouillon C. Morge D. and Ferrier J.P. (2009) Mapping wildland-urban interfaces at large scales integrating housing density and vegetation aggregation for fire prevention in the South of France, Journal of Environmental Management 91 (2010) $732-741$ author-produced version of the final draft post-refeering

the original publication is available at http://www.elsevier.com - doi:10.1016/j.jenvman.2009.10.001

ture and Forest Administration in the Bouches-du-Rhône. This database contains 104 wildland fires corresponding to a fire covering more than ten hectares recorded between 1990 and 2007.

\section{Method for mapping wildland-urban interfaces}

In France, WUI is defined according to the French Forest Orientation Law of July 9, 2002, which makes brush clearing obligatory within a maximum radius of 100 meters around each house located at a distance of less than 200 metres from forests or scrublands (Fig.2). This 100-metre radius distance was also reported to be useful by Kaval (2009). In the present study, only houses used as dwellings i.e. where people live permanently, temporarily or seasonally were taken into consideration. Agricultural, industrial, commercial and public buildings were not included.

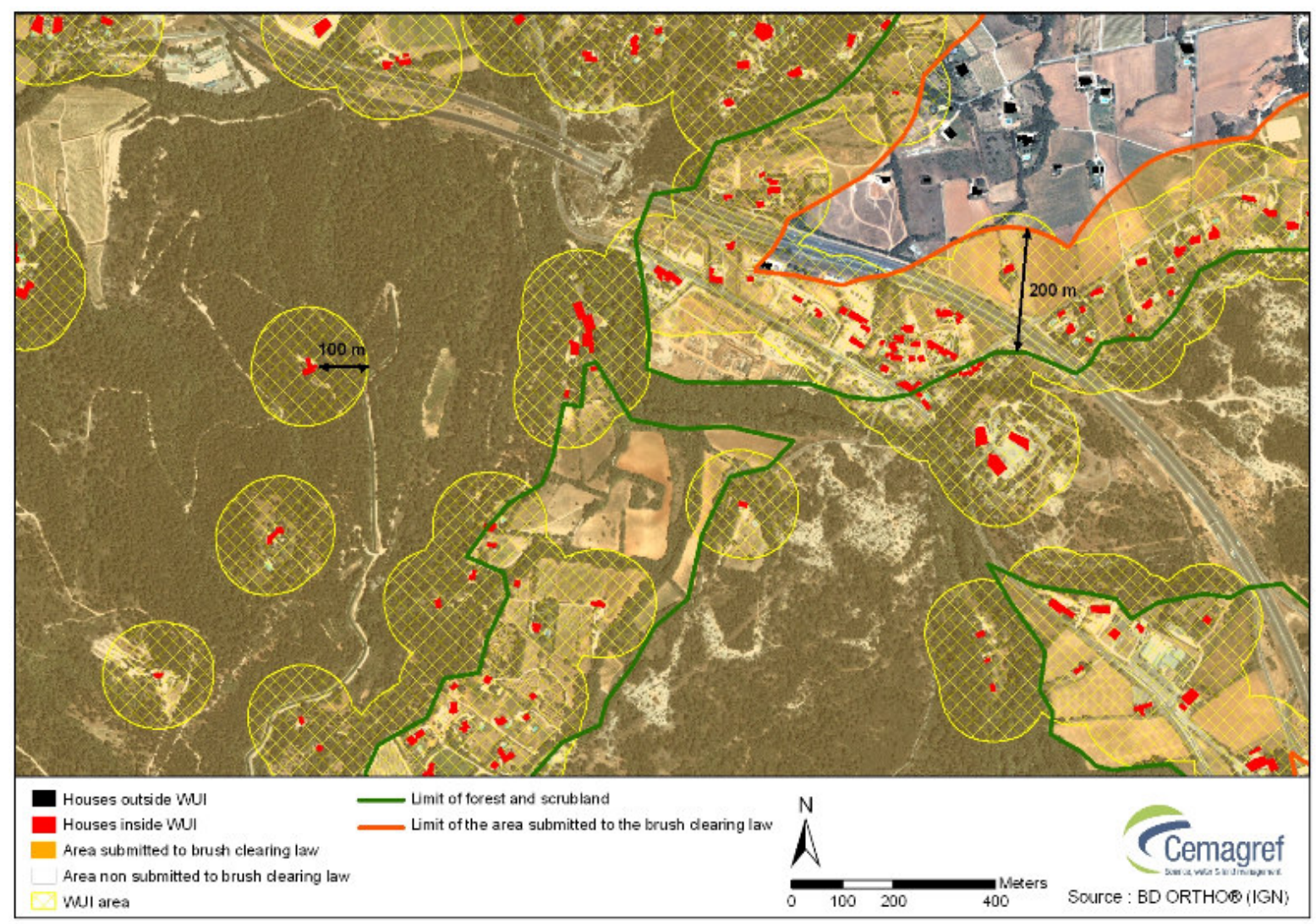

Figure 2: Definition of wildland-urban interface

The method used to characterize and map WUIs was based on three steps. First, using ARCGIS ${ }^{\circledR}$ 9.1, the configuration of houses was identified based on the houses in the area that were subject to the brush clearing law (Fig.3a). We classified each house in one of the four housing configuration types: isolated, scattered, dense clustered, and very dense clustered houses according to the method developed by Lampin-Maillet et al. (2009) (Fig.3b). The resulting vector layer was con- 
Lampin-Maillet C.,Jappiot M., Long M., Bouillon C., Morge D. and Ferrier J.P. (2009) Mapping wildland-urban interfaces at large scales integrating housing density and vegetation aggregation for fire prevention in the South of France, Journal of Environmental Management 91 (2010) 732-741 author-produced version of the final draft post-refeering

the original publication is available at http://www.elsevier.com - doi:10.1016/j.jenvman.2009.10.001

verted into raster format and recoded in four housing configuration classes: isolated, scattered, dense clustered and very dense clustered houses (Fig.3c).

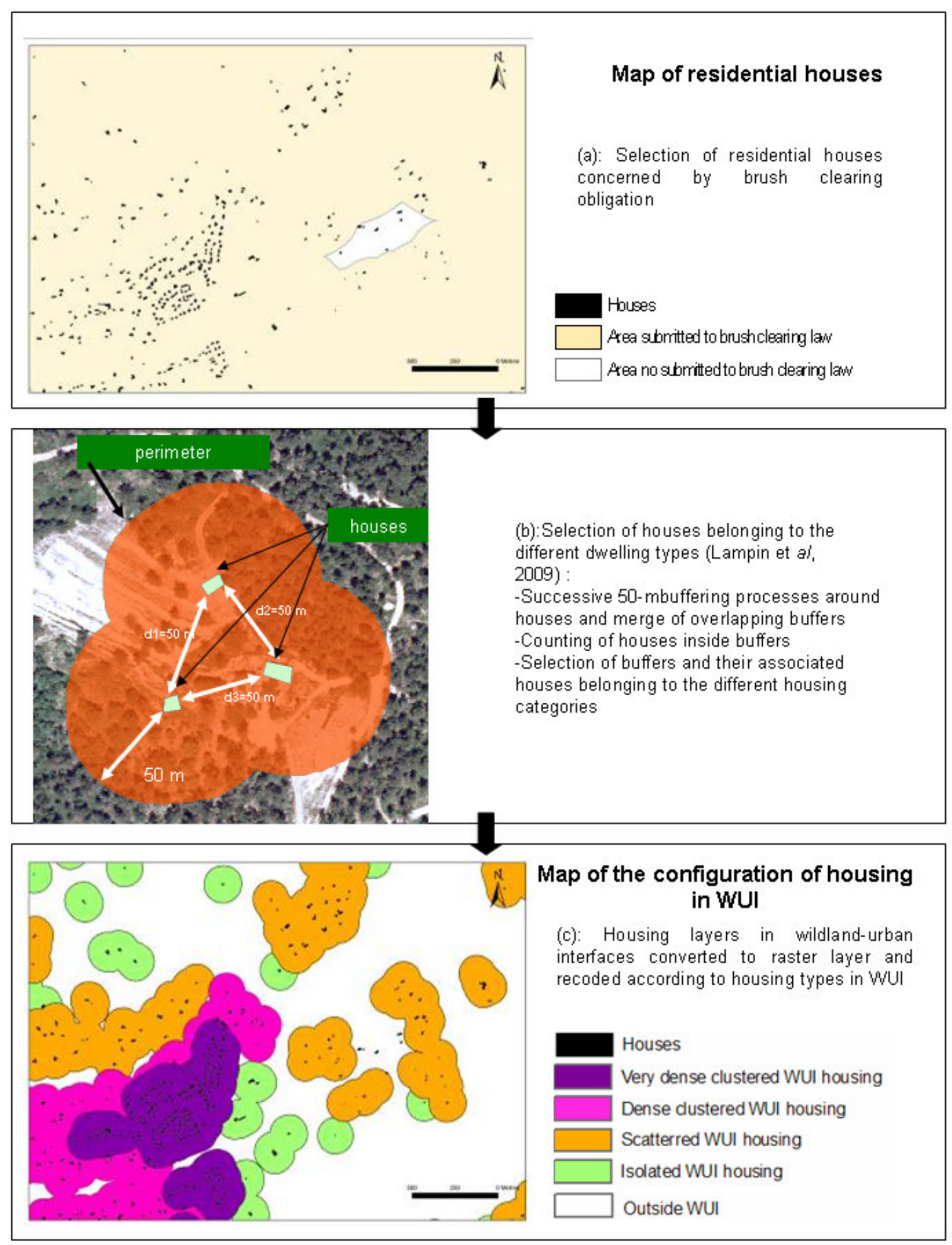

Process for mapping the configuration of houses in WUI

Figure3: Process for mapping the configuration of houses in WUI 
Lampin-Maillet C.,Jappiot M., Long M., Bouillon C., Morge D. and Ferrier J.P. (2009) Mapping wildland-urban interfaces at large scales integrating housing density and vegetation aggregation for fire prevention in the South of France, Journal of Environmental Management 91 (2010) 732-741 author-produced version of the final draft post-refeering

the original publication is available at http://www.elsevier.com - doi:10.1016/j.jenvman.2009.10.001

Second, the structure of vegetation was characterized and mapped to emphasise its horizontal continuity (no vegetation, sparse vegetation and continuous vegetation) but without trying to accurately map fuel vegetation. Landscape ecology includes numerous metrics to enable the translation of the composition and structure of a landscape (McGarigal, 2002), and was used to extract information about landscape composition and structure. Among existing metrics, the most appropriate index to measure aggregation of spatial patterns is the aggregation index (Turner, 1990), which can be mapped using FRAGSTATS3.3@ software (McGarigal \& Marks, 1994). As a configuration (or spatial) metric, it refers to the spatial arrangement and agglomeration of pixels of vegetation on the image. It provides information about the frequency of connections between the pixels (RobbezMasson et al., 1999). The formula for the aggregation index is:

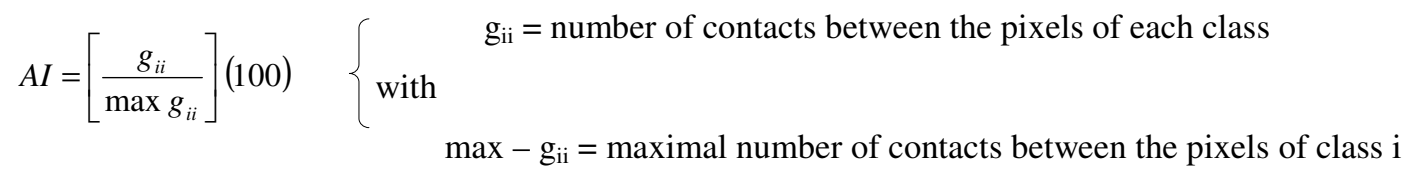

The aggregation index was calculated from the vegetation class (raster layer) using a moving window with a radius of 20 metres. Results ranging between 0 and 100 were recoded into three classes. The first class included values equal to zero, and the two other classes were determined by sharing the other values equally in two groups: low and high aggregation values. Figure 4 shows the resulting raster layer recoded into these three classes of vegetation structure (zero aggregation, low aggregation and high aggregation). 


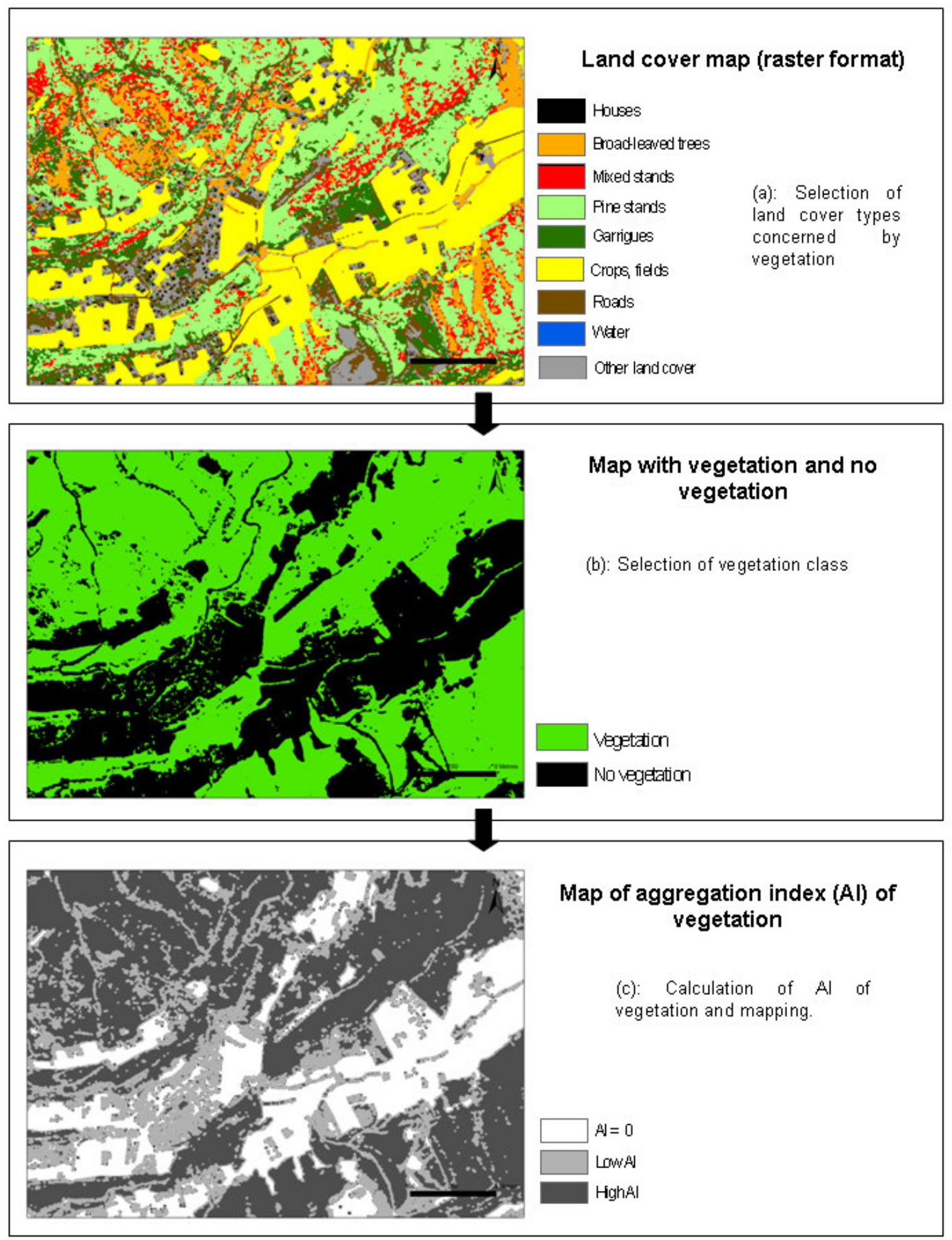

\section{Process for mapping the structure of vegetation in WUI}

Figure 4: Process for mapping the structure of vegetation in WUI

The third step combined the two previous raster layers using a geographical information system (GIS). The two raster layers were intersected. A WUI map was made according to 12 types (Fig. 5) 
.Maillet C Jappiot M. Long M., Bouillon C. Morge D. and Ferrier J.P. (2009) Mapping wildland-urban interfaces at large scales integrating housing density and vegetation aggregation for fire prevention in the South of France, Journal of Environmental Management 91 (2010) 732-741 author-produced version of the final draft post-refeering

the original publication is available at http://www.elsevier.com - doi:10.1016/j.jenvman.2009.10.001

by crossing the four classes of housing configuration and the three classes of vegetation aggregation indexes in a raster format. The 12 types were also illustrated with photos taken in the field (Fig. 6).

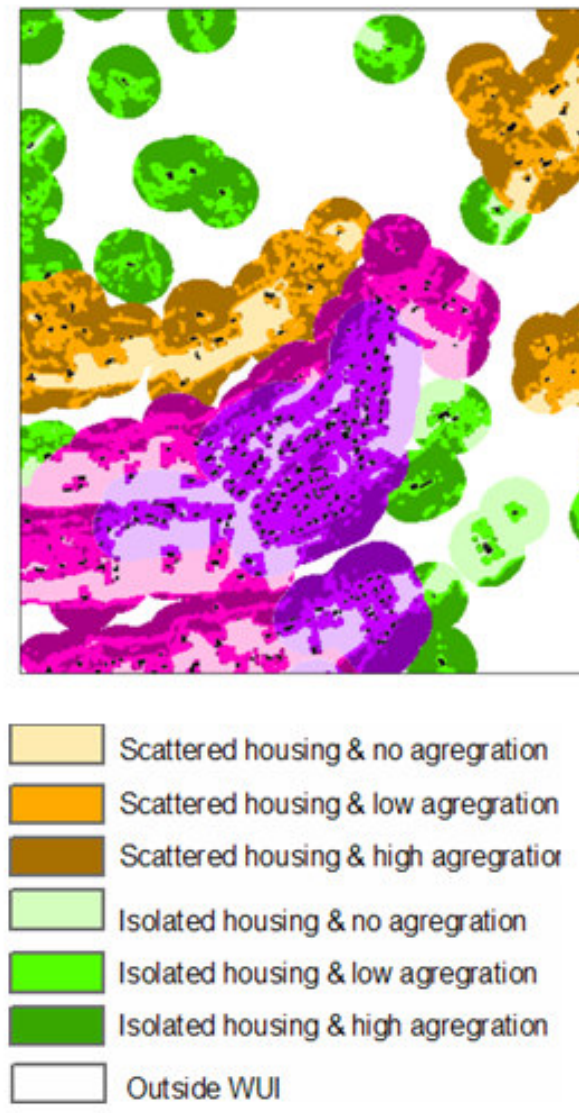

\section{Map of wildland urban interfaces}

Figure 5: Mapping of WUI by combining configuration of houses and structure of vegetation 


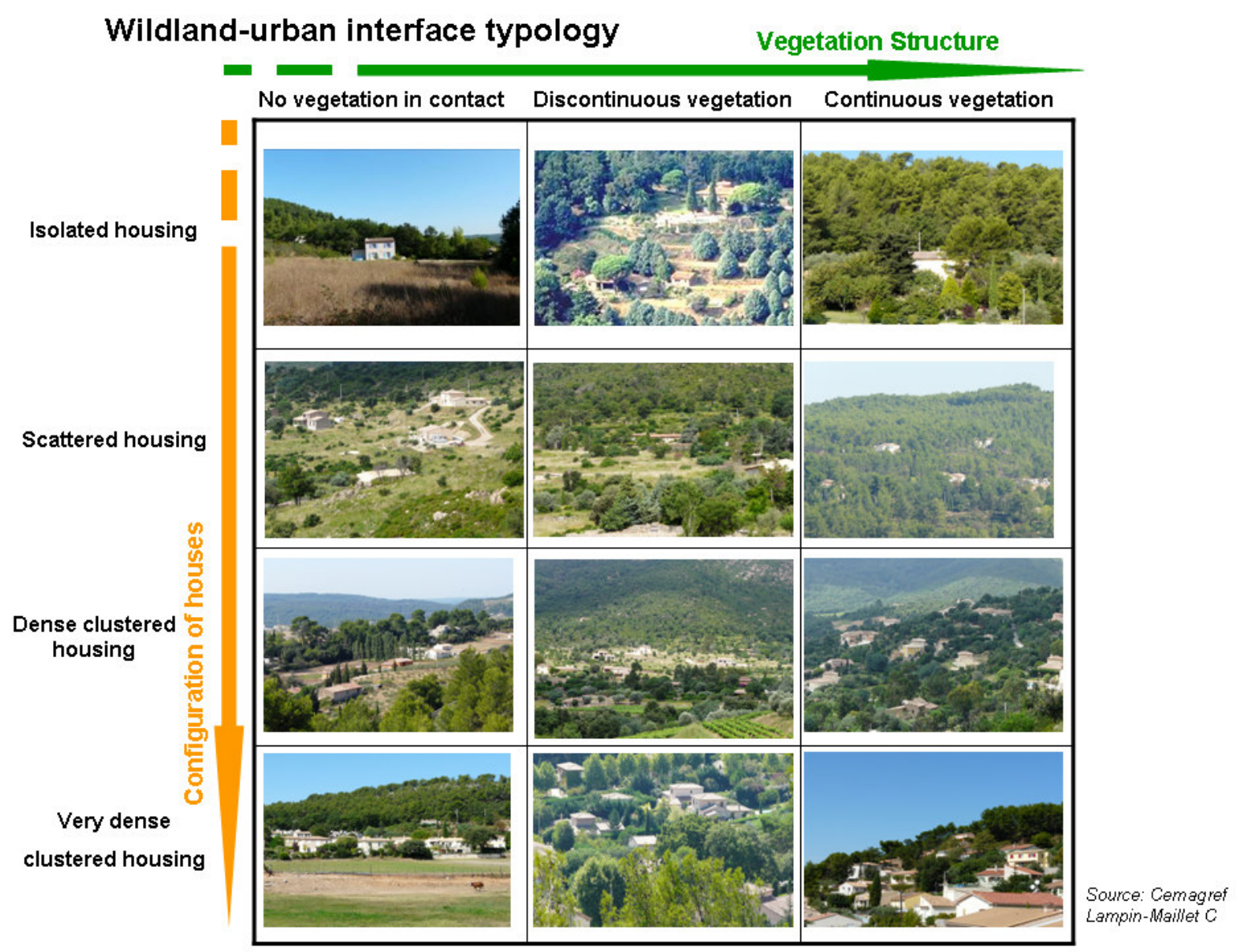

Figure 6: 12 Typology of Wildland-Urban interfaces

\section{Method for analysing the relationship between WUIs and fire data}

To assess fire risk components, we studied fire occurrence through the distribution of fire ignition points and vulnerability through the distribution of burned areas. The WUI map was intersected with the map of the spatial distribution of fire ignition points. An indicator of fire ignition density was calculated as the number of ignition points in each type of WUI (or outside the WUI) divided by the area of each type of WUI (or the area located outside the WUI). The result was expressed as the number of fire ignition points per 1000 hectares. We used the $\chi^{2}$ test to check if results were significantly higher within areas classified as WUIs than in other zones.

The WUI map was also intersected with the map of the spatial distribution of burned areas. An indicator called 'burned area ratio' was calculated as the burned area in each type of WUI (or outside the WUI) divided by the area of each type of WUI (or by the area located outside the WUI). The resulting ratio was expressed as a percentage of the burned area for each type of WUI. 
ampin-Maillet C. Jappiot M., Long M., Bouillon C., Morge D. and Ferrier J.P. (2009) Mapping wildland-urban interfaces at large scales integrating housing density and vegetation aggregation for fire prevention in the South of France, Journal of Environmental Management 91 (2010) $732-741$ author-produced version of the final draft post-refeering

the original publication is available at http://www.elsevier.com - doi:10.1016/j.jenvman.2009.10.001

\section{RESULTS}

\section{Typology of wildland-urban interfaces (WUI)}

WUIs represented $30 \%$ of the study area and $56 \%$ of houses were accounted for in wildland-urban interfaces. Figure 7 shows the proportion of the different types of WUI. Based on the configuration of the housing, 12\% was isolated housing, 25\% scattered housing, $28 \%$ dense clustered housing, and $35 \%$ very dense clustered housing. Based on vegetation structure, $38 \%$ had an aggregation index equal to zero, $45 \%$ had a low aggregation index and $17 \%$ a high aggregation index. An aggregation index equal to zero corresponded to areas with no wildland vegetation, which were generally covered by crops or were bare ground. A high aggregation index meant that vegetation was always present. A low aggregation index indicated more open areas, which could be adjacent to areas with no vegetation.

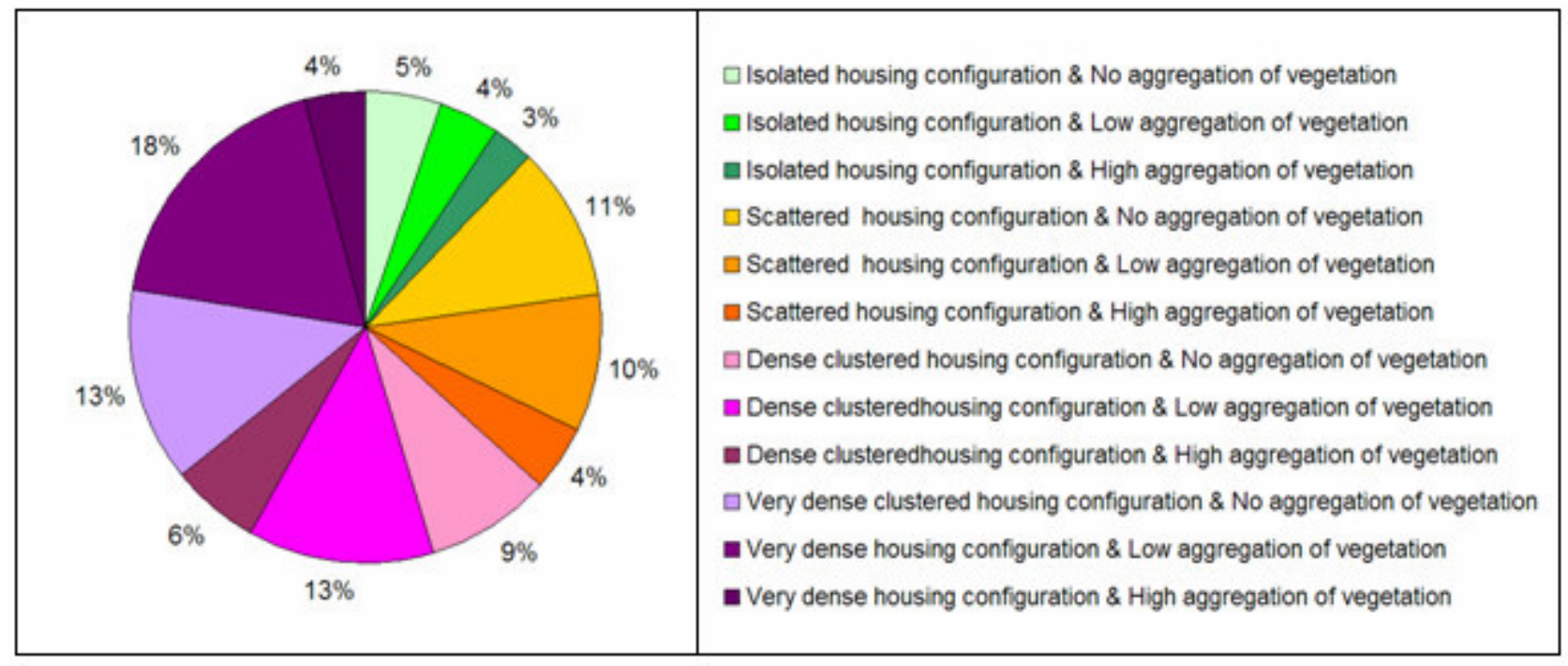

Figure 7: Distribution of the WUI types in the study area

Figure 8 shows the distribution of the main land cover types within WUI areas and outside. Three main features became apparent. First, there was more vegetation outside the WUIs than within corresponding to garrigues and sparse vegetation. Within the WUIs, vegetation was predominant and covered more than $40 \%$ of the area of all types of WUI except in the very dense clustered WUIs. Conifers and mixed stands were more common in the WUIs than outside. The proportion of hardwood stands was the highest outside the WUIs. Second, except in very dense clustered WUIs, there was more agricultural land in the WUIs than outside, particularly in isolated and scattered WUIs. Third, urban areas were almost the same in isolated WUIs and outside WUIs. Urbani- 
zation increased greatly from isolated WUIs to scattered to clustered WUIs. The proportion of urban area was the highest in very dense clustered WUIs (4.6 times higher than in isolated WUIs).

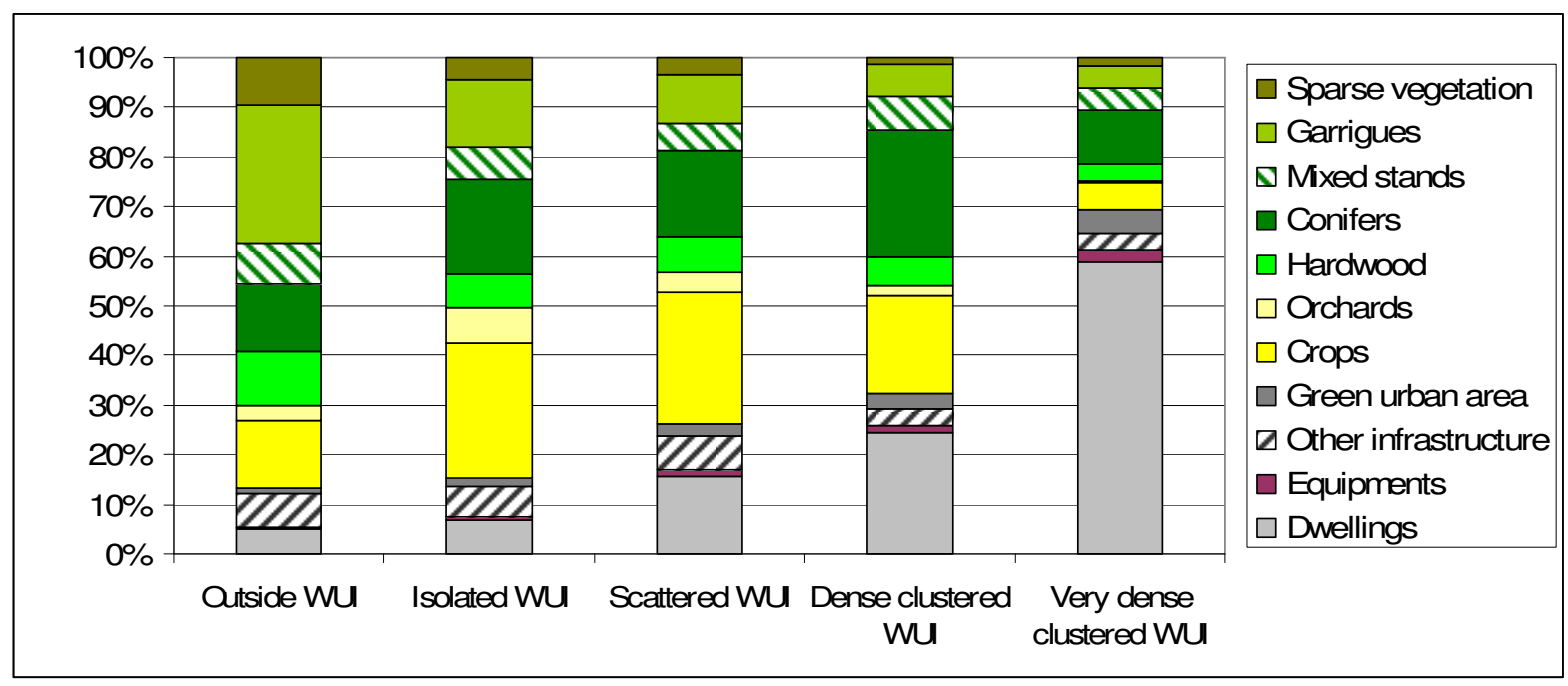

Figure 8: Land cover distribution according to WUI types in the study area

\section{Relationships between WUIs and fire data}

\section{Fire ignition points}

The mean fire ignition density value for the study area reached 3.4 fire ignition points per 1000 hectares. It was significantly higher in WUIs with five fire ignition points per 1000 hectares: around twice as high in WUIs than outside (results of $\chi^{2}$ test with $1 \%, \chi^{2}$ contributions: $69.3 \%$ in WUIs and $-30.3 \%$ outside).

Within WUIs, the fire ignition density was calculated for each type of WUI (Fig.9). Our results showed that the density value was 3.4 times higher for isolated WUIs than for clustered WUIs. Fire ignition density values increased greatly with a decrease in housing density (results of the $\chi^{2}$ test with $1 \%$ o). At the same time, the density value was 2.2 times higher when the aggregation index inside the WUI was high than when it was equal to zero. Fire ignition density values increased greatly with an increase in the aggregation index. The WUI characterized by isolated housing and a low aggregation index had the highest density value 


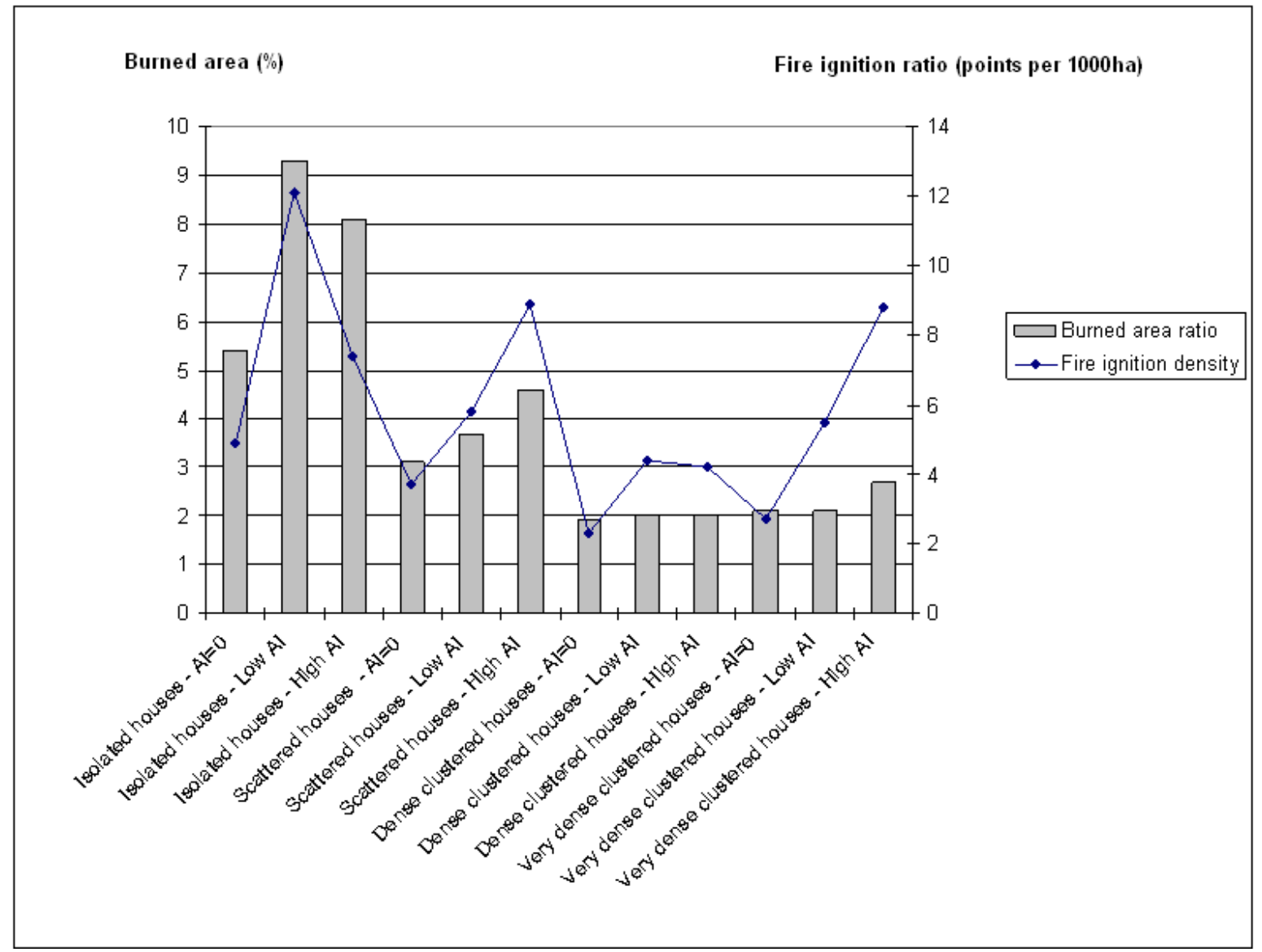

Figure 9: Fire ignition density and burned area ratio according to WUI types in the study area

\section{Burned area}

The burned area ratio for the study area was $13.2 \%$. This value was 4.2 times lower in WUIs with a burned area ratio of $3.1 \%$; 5.6 times lower in the WUIs than outside (with a ratio of $17.2 \%$ ). Within WUIs, the burned area ratio was calculated for each type of WUI (Fig.9). There was an increase in the burned area ratio with a decrease in housing density. The ratio was 3.7 times higher for isolated WUIs than for clustered WUIs, two times higher for isolated WUIs than for scattered WUIs, and 1.4 times higher for a high aggregation index in the WUIs than for an aggregation index equal to zero in the WUIs. The ratio increased with an increase in the aggregation index. The WUI characterized by isolated housing and a low aggregation index had the highest burned area ratio.

\section{DISCUSSION}

\section{WUI characterization and fire risk}

Our results allowed the characterization and mapping of 12 types of WUI types over a large area and at a large scale using precise data. We quantified the spread of the WUIs over the study area. 
Housing development in or near wildland vegetation is widespread: $30 \%$ of the area and more than the half the houses or buildings are located in wildland urban interfaces. Because WUIs are areas where wildland fire destroys the most dwellings when fuel and weather are conducive to fire (Covington, 2000 cited by Radeloff et al (2005b) and where human-caused fire ignitions are most common (Cardille et al, 2001), WUIs are now priority areas for controlling wildfire (Stephens, 2005 in Zhang \& Winberley, 2007).

Around half the WUIs in our study had dense or very dense clustered housing with a low or zero aggregation index of vegetation. These areas are located in the proximity of two big cities (Marseilles and Aix-en-Provence). Isolated WUIs represented only 12\% of WUI types but this low proportion nevertheless represents a large area.

Regarding fire ignition density and burned area ratio, isolated WUIs with low and high aggregation indices of vegetation presented the highest values although they only represented $2.1 \%$ of the area. Scattered WUIs (4.2\% of the area) with both low and high aggregation indices of vegetation also represented a high level of fire ignition density and burned area ratio even if these values were lower than those for isolated WUIs. Our results also highlighted the fact that the burned area ratio generally decreased from isolated WUIs to dense and very dense clustered WUIs, and also decreased from a high aggregation index to a zero aggregation index. This can be explained by the corresponding decrease in the proportion of wildland vegetation within WUIs counterbalanced by an increasing proportion of urban areas. Below $30 \%$ of wildland vegetation cover, the connectivity of burnable vegetation is lost and fire spread is limited. When the proportion of urbanized area is high, the continuity of burnable wildland is interrupted (Syphard et al., 2007b), which was the case of very dense clustered WUIs (more than $60 \%$ of urbanized area). In addition, as suggested by Sturtevant \& Cleland (2007), isolated homes may be more at risk from large fires, perhaps owing to delays in fire reporting or increased response times. Our results also showed that fire risk is not zero in WUIs with no wildland vegetation ( $1.9 \%$ to $5.4 \%$ of burned area). These areas burn easily when they are dry and there are many examples of fire propagation due to burning crops (Sturtevant \& Cleland, 2007).

\section{Suggestions in terms of land management and fire management}

Around $7 \%$ of the territory appeared to be the most vulnerable to wildfire and the most concerned by fire ignition. These results suggest that specific actions are needed:

(i) In terms of forest and fire management, the strengthening of individual or collective protective actions (clearing brush by removing biomass, and pruning trees to interrupt the horizontal and 
vertical continuity of vegetation and thus mitigate fire propagation. There is increasing concern about the removal and reduction of fuel (Cohen, 2000; Conard et al., 2001). The mean area to be cleared as defined in Lampin-Maillet et $a l$, (2009) is the lowest in very dense clustered WUIs (10 times smaller than in isolated WUIs with isolating housing). Consequently in isolated WUIs with around 1 ha to be cleared regularly, brush clearing actions are probably less feasible than in clustered WUIs. The WUI map covers an area in the South of France that was taking part in a Forest Fire Risk Prevention Plan at the municipal level required by the French "Ministère de l'Ecologie, $d u$ Développement et de l'Aménagement Durables". To encourage less carelessness and hence decrease fire ignition potential, appropriate fire prevention information should be widely diffused among the general public;

(ii) In terms of land management, isolated housing should be avoided and compact urban development and densification of housing encouraged. These preventive measures should help decrease the level of fire risk in the main WUIs concerned.

\section{Data requirements for mapping WUI types}

Analyses and assessment of fire risk related to WUIs were performed using available accurate data concerning our study area in terms of the configuration of houses and past fires (layers of burned areas and digitized fire ignition points). The findings of this study improved our knowledge of the territory and suggest that accurate data, particularly on past fires, are necessary. Targeted actions should be encouraged such as improving the determination of fire causes (Long et al., 2008), more precise identification of fire ignition points, and the efficient investigation of the causes of fires to enhance the efficiency of forest fire prevention in the medium term. Despite the need for accurate data, this method has already been successfully applied by one French administrative department (Hérault) for an area of 611000 ha.

\section{CONCLUSION}

In this paper we proposed a reproducible method for characterizing and mapping WUIs at large scales and over large areas. We have shown that certain types of WUIs represent a high level of fire risk in terms of fire ignition density and burned area ratio. These results could have interesting implications for fire prevention and land management.

WUIs have increased considerably all over the world in recent decades and this trend will certainly continue in the coming years due to the pursuance of the land abandonment process combined with urbanization. The method we developed for mapping WUIs is an appropriate tool for the 
Lampin-Maillet C.,Jappiot M., Long M., Bouillon C., Morge D. and Ferrier J.P. (2009) Mapping wildland-urban interfaces at large scales integrating housing density and vegetation aggregation for fire prevention in the South of France, Journal of Environmental Management 91 (2010) $732-741$ author-produced version of the final draft post-refeering

the original publication is available at http://www.elsevier.com - doi:10.1016/j.jenvman.2009.10.001

assessment of WUI dynamics and associated fire risk dynamics in the context of ongoing changes in climate, urbanization and vegetation.

\section{ACKNOWLEDGMENTS}

The work was partially financed by the French "Ministère de l'Ecologie, du Développement et de l'Aménagement Durables", "Conseil Régional Provence-Alpes-Côte-d'Azur”, integrated project Fire Paradox $\mathrm{n}^{\circ}$. FP6-018505. The authors wish to thank them. They also acknowledge the firefighters of the "Service d'Incendie et de Secours du Var", and the foresters of the "Direction Territoriale Méditerranée de l'ONF" for their contribution. The authors would also like to thank A.L. Gill and four anonymous reviewers for their help in improving this paper.

\section{BIBLIOGRAPHY}

Alberti, M. (1999). Urban patterns and environmental performance: what do we know? J. Plann. Educ. Res. 19 (2), 151-163.

Avalapati, J.R.R., Carter, D.R., \& Newman, D.H. (2005). Wildland-Urban Interface: challenges and opportunities. Forest Policy and Economics, 7, 705-708.

Badia-Perpinya, A., \& Montserrat-Pallares, B. (2006). Spatial distribution of ignitions in Mediterranean periurban and rural areas: the case of Catalonia. International Journal of Wildland Fire,15, 187-196

Caballero, D. (2004) Conclusions of the Third WARM workshop on forest fires in the wildland-urban Interface in Europe. Madrid, Spain, 26-27th of May. WARM Project Final Report. European Commission.

Camia, A., Valera, V., Marzano, R., \& Etchifidis, G. (2003). Spatial analysis in European Wildland-urban interface environment using GIS. WARM project, http://www.fria.gr/chapters/warmCh21Camia.pdf.

Cardille, J.A., Ventura, S.J., \& Turner, M.G.(2001). Environmental and social factors influencing wildfires in the Upper Midwest, United states. Ecological applications, 11, 111-127

Cohen, J. D. (2000). Preventing disaster: home ignitability in the wildland-urban interface. Journal of Forestry, 98:15-21.

Collinge, S. (1996). Ecological consequences of habitat fragmentation: implications for landscape architecture and planning. Landscape Urban Planning. 36, 50-77.

Collins, T.W. (2005). Households, forests, and fire hazard vulnerability in the American West: A case study of a California community. Environmental Hazards, 6, 23-37.

Conard, S.G., Hartzell, T., Hilbruner, M.W., \& Zimmerman, G.T. (2001). Changing fuel management strategies - The challenge of meeting new information and analysis needs. International Journal of Wildland Fire, 10, 267-275.

Davis, J.B. (1990). The wildland-urban interface: paradise or battleground? Journal of forestry, 88(1), 26-31. 
Dumas, E., Jappiot, M., \& Tatoni, T. (2008). Mediterranean urban-forest interface classification (MUFIC): A quantitative method combining SPOT5 imagery and landscape ecology indices. Landscape and Urban Planning, 84, 183-190.

Eufirelab (2004). Bonora, L., Conese, C., Lampin, C., Martin, P., Martinez, J., Molina, D., Salas, J. Towards method for investigating on wildland fire causes. Eufirelab: Euromediterranean wildland fire laboratory, a "wall-less" laboratory for wildland Fire Sciences and Technologies in the Euro-Mediterranean region. Deliverable D-05-02. $43 \mathrm{p}$.

Haight, R. G., Cleland, D.T., Hammer, R.B., Radeloff, \& V.C., Rupp, S.S. (2004). Assessing Fire Risk in the Wildland-Urban Interface—a landscape ecosystem approach. Journal of Forestry, 102, 41-48.

Hardy, C.C. (2005). Wildland fire hazard and risk: Problems, definitions, and context. Forest ecology and management. 211, 73-82.

Jappiot, M., Gonzales-Olabarria, J.R., Lampin-Maillet, C., Borgniet, L. (2009). Assessing wildfire risk in time and space. In Living with wildfires: What science can tell us? A contribution to the science-policy dialogue; Ed Yves Birot. P 41-47.

JRC. (2006). Statistics 1980-2006, data source JRC-IES Report nº7/2006

Kamp, M., \& Sampson, N. (2002). "Using GIS to identify potential wildland-urban interface areas based on population density." www.sampsongroup.com/Papers/wui_paper.pdf.

Kaval, P. (2009).Perceived and actual wildfire danger : an economic and spatial analysis study in Colorado (USA). Journal of Environnement Management. 90 (2009) 1862-1867.

Keane, R. E., Burgan, R., Van Wagtendonk, J. (2001). Mapping wildland fuels for fire management across multiple scales: integrating remote sensing, GIS, and biophysical modelling. International Journal of Wildland Fire. 10, 4, 301-319.

Lampin-Maillet, C., Jappiot, M., Long, M., Morge, D., \& Ferrier, J.P. (2009). Characterization and mapping of dwelling types for forest fire prevention. Computers, Environment and urban systems, 33 (2009), pp. 224-232, doi:10.1016/j.compenvurbsys.2008.07.003

Lampin-Maillet, C., (2008). 2007, Summer Fires in the European Mediterranean - The Cases of Greece, Italy and Spain. Mediterranean yearbook. European Institute of the Mediterranean. Med.2008, Economy and Territory- Sustainable Development, 243-247. http://www.iemed.org/anuari/2008/aarticles/EN243.pdf.

Lampin, C., Jappiot, M., Long, M., Mansuy, N., \& Borgniet, L. (2006a). WUI and road networks/vegetation interfaces characterizing and mapping for forest fire risk assessment. Forest Ecology and Management, 234, Supplement 1, S137-S140.

Lampin, C., Jappiot, M., Borgniet, L., \& Long, M. (2006b). Cartographie des interfaces habitat-forêt : une approche spatiale pour estimer le risque d'incendie de forêt. Revue internationale de géomatique. European Journal of GIS and Spatial analysis, 16- n³-4/2006, 321-340.

Long, M., Ripert, C., Piana, C., Jappiot, M., Lampin, C., Ganteaume, A. (2008). Guide technique - Amélioration de la connaissance des causes de départ de feu de forêt. 116p. 
McGarigal, K. (2002). Landscape Pattern Metrics, Chapter of Encyclopedia of Environmentrics, Volume 2, John Wiley \& sons, Sussex, England, 1135-1142.

McGarigal, K., \& Marks, B.J. (1994). FRAGSTATS : spatial pattern analysis program for quantifying landscape structure. USDA Forest Service, Pacific Northwest Research Station, General technical report PNWGTR-351, Portland, OR.

Nowicki, B. (2002). The Community protection Zone: Defending houses and Communities from the threat of forest fire. http://www.biologicaldiversity.org/publications/papers/wui1.pdf.

Pew, K.L., \& Larsen, C.P.S. (2001). GIS analysis of spatial and temporal patterns of human-caused wildfires in the temperate rain forest of Vancouver Island, Canada. Forest ecology and management, 140, 1, 1-18.

Radeloff, V.C., Hammer R.B., \& Stewart, S.I. (2005a). Rural and suburban sprawl in the U.S. Midwest from 1940 to 2000 and its relations to forest fragmentation. Conserv. Biol, 19 (3), 793-805.

Radeloff, V.C., Hammer R.B., Stewart, S.I., Fried, J.F., Holcomb, S.S., \& McKeefry, J.F. (2005b). The wildland urban interface in the United States. Ecological applications, 15 (3), 799-805.

Robbez-Masson, J.M., Foltête, J.C., Cabello, L., \& Flitti, M. (1999). Prise en compte du contexte spatial dans l'instrumentation de la notion de paysage. Application à une segmentation géographique assistée. Revue internationale de Géomatique, Volume 9.2, 173-195.

Stewart, S.I., Radeloff, V.C., Hammer, R.B., \& Hawbaker, T.J. (2007). Defining the Wildland-Urban Interface. Journal of Forestry, 201- 207.

Stewart, S.I., Radeloff, V.C., \& Hammer R.B. (2003). Characteristics and location of the Wildland-UrbanInterface in the United States, 6. http://ams.confex.com/ams/FIRE2003/techprogram/paper_65316.htm

Sturtevant, B.R., \& Cleland, D.T. (2007). Human and biophysical factors influencing modern fire disturbance in northern Wisconsin. International Journal of Wildland Fire, 16, 398-413.

Syphard, A.D., Radeloff, V., Keeley, J., Hawbaker, T.J., Clayton, M.K., Stewart, S.I., \& Hammer, R.G. (2007a). Human influence on California regimes. Ecological applications, 17(5), 1388-1402.

Syphard, A.D., Clarke, K.C., \& Franklin, J. (2007b). Simulating fire frequency and urban growth in southern California coastal shrublands, USA. Landscape Ecology, 22, 431-445.

Theobald, D.M., \& Romme, W.H. (2007). Expansion of the US wildland-urban interface. Landscape and Urban Planning, 83, 340-354.

Turner, M.G. (1990). Landscape changes in nine rural counties of Georgia. Photogrammetry Engineering and Remote sensing. 56, 379-386.

Vélez, R. (1997). Recent history of forest fires in Mediterranean area. In: Balabanis P, Eftichidis G, Fantechi R (eds) Forest fire risk and management. Proceedings of the European School of Climatology and Natural Hazards , Greece, 27 May-4 June 1992. European Commission, Brussels, 15-26.

Zhang, Y., \&Winberly, M.C. (2007). The importance of scale in using hierachical Census data to identify the Wildland-Urban interface. South. J. Appl. For, 31(3), 138-147. 